\title{
PROXIMATE AND MORPHOLOGICAL CHARACTERISTICS OF NANO HYDROXYAPATITE (NANO HAP) EXTRACTED FROM FISH BONE
}

\author{
MOHAMAD RAIS HASAN ${ }^{1}$, NORFATIN SYAZANI MOHD YASIN ${ }^{1}$, MOHD SABRI MOHD \\ GHAZALI $^{2}$ AND NOR FAZLIYANA MOHTAR*1
}

${ }^{1}$ Faculty of Fisheries and Food Science, ${ }^{2}$ Faculty of Science and Marine Environment, Universiti Malaysia Terengganu, 21030, Kuala Nerus, Terengganu, Malaysia.

*Corresponding author: fazliyana@umt.edu.my

Submitted final draft: 1 May $2020 \quad$ Accepted: 11 May 2020

http://doi.org/10.46754/jssm.2020.12.002

\begin{abstract}
Hydroxyapatite (HAp) with the chemical formula $\left(\mathrm{Ca}_{10}\left(\mathrm{PO}_{4}\right)_{6} \mathrm{OH}_{2}\right)$ is an inorganic mineral component that has wide application in many fields. It can be produced from natural sources like bovine, coral and porcine. However, such sources (bovine and porcine) contradict religious prohibition. Besides, the abundance of fish waste from fish processing industries has contributed to environmental pollution. To overcome this issue, this study was shifted towards the utilisation of marine source as a raw material for HAp production which could ensure the sustainability of fisheries resources. This study aimed to extract nano-hydroxyapatite (HAp-1) from spotted sardinella (Amblygaster sirm) bone and to characterise their morphology using a Scanning Electron Microscope (SEM) and proximate composition. The extraction was carried out via calcination at different temperatures which ranged from 600 to $1000^{\circ} \mathrm{C}$. Proximate composition of raw bone $(\mathrm{RB})$ was higher (protein $=1 \%$, ash $=50 \%$, moisture $=10 \%$ and lipid $=3 \%$ ) than the extracted HAp-1 (protein $=3 \%$, ash $=1 \%$, moisture $=98 \%$ and lipid $=1 \%$ ) that indicates the decomposition of materials in initial RB. Yield percentage of HAp-1 ranged from 50 to $53 \%$ depending on the calcination temperatures. Colour changes $(\Delta \mathrm{E})$ value of HAp- 1 was ranged from 17 to $29 \Delta \mathrm{E}$ for different calcination temperatures $\left(600\right.$ to $\left.1000^{\circ} \mathrm{C}\right)$, the lowest colour changes value $(\Delta \mathrm{E}=17)$ is comparable with the standard which indicates pure HAp obtained. Meanwhile, the morphological structure of HAp-1 demonstrated irregular spherelike shape compared to standard (consistent spherical particles) which was influenced by the source and method for the extraction of HAp. The overall finding in this study could contribute to further extension of method development for HAp extraction through the utilisation of new species of spotted sardinella bone. The extracted HAp can be applied for many applications and fulfil any market demands without contradicting any issues.
\end{abstract}

Keywords: Fish bone, Nano-HAp, proximate composition, morphology, potential.

\section{Introduction}

Fish is one of the major sources of protein, vitamins and minerals for human consumption. Thus, it is widely consumed all over the world due to its high protein content and low fat which is good for human health. This phenomenon has contributed to the abundance of fish waste left untreated that can pollute the environment (Elvevoll \& James, 2001). Fish waste management becomes a major problem recently in metropolis area due to overload of waste discharged from industries (Ozawa et al., 2002). Fish waste such as bone, skin, head and scale contains high biological components that can be turned into useful products (Elvevoll \& Osterud, 2003).

Hydroxyapatite (HAp) is a combination of calcium and phosphate elements that has been widely used in many applications, especially in medical, pharmaceutical and dentistry fields. The HAp scaffold can potentially promote cell colonisation and formation of new healthy bone along with the original bone due to high bioactivity properties that are suitable to be used in many applications (Santosh et al., 2009). Besides, the extraction process of HAp consists of the natural and synthetic method where its production from natural sources is 
preferable due to low-cost and is uncomplicated. The chemical extraction methods of HAp include sol-gel (Liu et al. 2002), wet chemical precipitation (Mobasherpour et al., 2007), hydrothermal (Bahrololoom et al., 2009) and microwave irradiation (Liu et al., 2004). However, the production of HAp from bio-waste is environmentally friendly and economically safe. Natural sources of HAp such as bovine bone (Barakat et al., 2009), shell (Adak \& Purohit, 2011), coral, fish bones (Rozaini et al., 2017) and scales (Liu et al., 2008) are high in other trace elements inherited from natural bone. HAp can be manufactured in various forms such as a dense ceramic (Kong et al., 2002), powder, ceramic coating (Ben-Nissan et al., 2004) and porous ceramic (Ozgur \& Caneyt, 1999) as required for specific applications. Currently, natural Hap is commonly derived from animalbased such as bovine and porcine bone. However, such sources of HAp production have an issue with religious prohibitions and diseases which decrease the demand from those sources. There are many reasons to substitute both mammalian sources with fish as an alternative source of HAp because the demand for HAp is increasing especially in the medical and pharmaceutical industries. The production of HAp from porcine source commonly contradicts with Muslim and Jewish prohibition. Furthermore, the concern over Bovine Spongiform Encephalopathy (BSE) disease also decreases the confidence of HAp extracted from bovine.

Therefore, the production of HAp from fish source is acceptable for everyone and free from infection of viral or other diseases. Many studies have reported on the production of HAp from fish source as a raw material for HAp extraction (Coelho et al., 2007; Mondal et al., 2012; Sunil \& Jagannatham, 2016; Corrêa and Holanda, 2019; Karim et al., 2019). However, they are still gaps in knowledge and less discovered compared to other biological sources. The development of the method using new species of fish is necessary for the extraction of HAp. Different species of fish may have different optimized method and properties. This study was carried out to retrieve the new species as source for HAp from fish by-products that are safer and more preferable compared to the mammalian sources. No discoveries and research have been made on the production of HAp using spotted sardinella (Amblygaster sirm). This of fish species is the most common species used for the production of food, especially for fish processing industries. The abundant waste from the industries were utilised in this study and turned into a valueadded product such as HAp.

The production of HAp from biological sources is usually obtained through the decomposition of organic materials such as lipid, protein and water. In relation to that, the composition of the organic materials needs to be evaluated for a proper extraction process. Furthermore, the structure of HAp is varied depending on the source and method of extraction. It can be in a spherical, rod-like and irregular shape which influences the properties and behaviour. Therefore, analysing the process of HAp structure is compulsory to ensure a precise characterisation process for application uses.

In this study, the production of HAp was carried out through calcination of fish bone collected from fish processing industries. Indirectly, it can help in reducing the amount of waste and turn it into value-added products that can be used as universal biomaterials for many applications. This study aimed to extract nano hydroxyapatite (nano-HAp) from spotted sardinella (Amblygaster sirm) bone and characterise its morphological characteristic and proximate composition.

\section{Materials and Methods}

\section{Preparation and Extraction of Hydroxyapatite}

A total of $100 \mathrm{~kg}$ of fish bones was collected from fish processing industries. The bones were washed thoroughly and boiled to remove excess meat. They were then dried in an oven for 24 hours. The dried bones were heated in a furnace (Carbolite ELF 11/14B/301, UK) at temperatures ranging from 600 to $1000^{\circ} \mathrm{C}$, with a heating rate of $10^{\circ} \mathrm{Cmin}^{-1}$ for 5 hours and it was cooled isothermally for 3 hours. The calcined 
bones were milled using the ball-mill (Retsch PM 100, Germany).

\section{Proximate composition}

The proximate analysis of raw bone (RB) was conducted according to the method of AOAC (2000). It was conducted to determine protein, ash, moisture and lipid content of $\mathrm{RB}$ and extracted nano-hydroxyapatite (HAp-1). Both samples were crushed into powder and sieved prior to the analysis. The proximate analysis was conducted for three replicates to get the average results.

\section{Protein}

A number of $0.2 \mathrm{~g}$ of RB and HAp-1 samples was weighed and placed in the Kjeldahl digestion flask and was recorded as W. An amount of 5 $\mathrm{ml}$ of concentrated sulphuric acid $\left(\mathrm{H}_{2} \mathrm{SO}_{4}\right)$ was mixed with a half tablet of catalyst in six test tubes except for blank. The test tube was shaken well and placed on a test tube rack for heating. The digestion process was conducted for about $40 \mathrm{mins}$ and a clear blue-green solution formed. The tube was cooled down for $15 \mathrm{mins}$.

An amount of $30 \mathrm{ml}$ of $4 \%$ boric acid was poured into a $250 \mathrm{ml}$ conical flask and eight drops of the mixed indicator were added into the conical flask. A number of $40 \mathrm{ml}$ of distilled water and $30 \mathrm{ml}$ of $40 \%$ sodium hydroxide $(\mathrm{NaOH})$ were added into the distillation tube. The first solution appeared red in colour. The conical flask was placed below the tip of the condenser with the tip immersed in the solutions. The distillation process was 3 mins and the conical flask was lowered so that the distillates can drop for $1 \mathrm{~min}$. The solution changed in colour from red to green solution.

The conical flask was then taken out and the titration process was continued with hydrochloric acid $(\mathrm{HCl})$. A number $0.1 \mathrm{~N} \mathrm{HCl}$ titrated with the distillates and the green solution turned pink in colour. The volume of $\mathrm{HCl}$ was recorded as $\mathrm{B}$. The amount of protein was calculated according to the formula below (AOAC, 2000):

\author{
Nitrogen $(\%)=\frac{T-B \times N \times 14.007}{W 2} \times 100 \%$ \\ $*$ Protein $(\%)=\mathrm{N} \mathrm{X} \mathrm{F}$ \\ $* \mathrm{~F}=$ Protein factor $(6.25)$ \\ $* \mathrm{~T}=$ Volume of HCL in titration $(\mathrm{ml})$ \\ $* \mathrm{~N}=$ Normality of $\mathrm{HCL}$ \\ *W2 = Weight of titrated sample (mg)
}

\section{Ash}

Crucible was dried in an oven at $100^{\circ} \mathrm{C}$ for 1 hour. The crucible was then cooled in the desiccator for $30 \mathrm{mins}$. The crucible and lid were weighed to four decimal places and and recorded as W1. A number of $2 \mathrm{~g}$ samples was put into the crucible with the samples and weighed and recorded as W2. The samples were then heated in a muffle furnace at $600^{\circ} \mathrm{C}$ for 3 hours. The lid was placed on top of the crucible during the heating process to prevent loss of ash. The samples were then cooled in desiccators and weighed (W3). The amount of ash was calculated according to the formula below (AOAC, 2000):

$$
\text { Ash }(\%)=\frac{W 3-W 1}{W 2-W 1} \times 100 \%
$$

$* \mathrm{~W} 1=$ Weight of crucible $(\mathrm{g})$

$* \mathrm{~W} 2=$ Weight of crucible + sample $(\mathrm{g})$

${ }^{*} \mathrm{~W} 3=$ Weight of crucible + ash $(\mathrm{g})$

\section{Lipid}

The extraction thimble was dried in an oven for 1 hour at $100^{\circ} \mathrm{C}$ and then cooled down in a desiccator and the weight was recorded as W1. An amount of $2 \mathrm{~g}$ of RB and HAp-1 were weighed and recorded as W2. The samples were placed inside the thimble. The extraction thimble was tied tightly at a ring holder and placed on a rack. The the metal heater, at the extraction unit using a holder. The reflux was set near to the dish to lock it neatly. Time was set for 1 hour with $15 \mathrm{mins}$ for opener thimble was then stuffed with cotton and the ring was stuck onto the magnet holder at the dish. An amount of 55 $\mathrm{ml}$ of petroleum ether solvent was filled into the dish by placing at boiling, 30mins for rinsing, $10 \mathrm{mins}$ for steam and $5 \mathrm{mins}$ for drying at a $900^{\circ} \mathrm{C}$ for petroleum ether to get solvent reflux stage until it gets three to five drops per second. The tap was then opened to allow the water to 
flow through a condenser. The temperature was then decreased to $90^{\circ} \mathrm{C}$ and the thimble was alighted until boiling. After $15 \mathrm{mins}$, the thimble was removed at the rinsing positions. The samples were placed in an oven for 2 hours at $100^{\circ} \mathrm{C}$ for the drying process. The dish was then cooled in a desiccator and weighed (W3). The amount of lipid was calculated according to the formula below (AOAC, 2000):

$$
\text { Lipid }(\%)=\frac{W 3-W 1}{W 2} \times 100 \%
$$

$* \mathrm{~W} 1=$ Weight of extraction thimble $(\mathrm{g})$

$* \mathrm{~W} 2=$ Weight of the initial sample $(\mathrm{g})$

*W3 $=$ Weight of extraction thimble + essential fats $(\mathrm{g})$

\section{Moisture}

The empty crucible and lid were dried in an oven for 1 hour at $100^{\circ} \mathrm{C}$ was then cooled in desiccators and the weight was recorded as W1. A number of $2 \mathrm{~g}$ of the RB and HAp-1 was weighed and placed inside the crucible (W2). The samples were placed in an oven at $100^{\circ} \mathrm{C}$ for 6hours. The crucible was transferred into desiccator for cooling with partially covered lid. The dried sample was then be reweighed. The amount of moisture was calculated according to the formula below (AOAC, 2000):

$$
\text { Moisture }(\%)=\frac{W 3-W 1}{W 2-W 1} \times 100 \%
$$

$* \mathrm{~W} 1=$ Weight of crucible $(\mathrm{g})$

$* \mathrm{~W} 2=$ Weight of crucible + sample $(\mathrm{g})$

$* \mathrm{~W} 3=$ Weight of crucible + dry sample $(\mathrm{g})$

*Moisture $(\%)=100$ - percentage of dried sample

\section{Percentage of yield}

The calculation of yield percentage (\%) was conducted on extracted HAp-1 obtained at temperatures ranging from 600 to $1000^{\circ} \mathrm{C}$ for determination of the optimum temperature. The yield was calculated according to the following equation (Ratnasary \& Firlianty, 2016):

$$
\text { Yield }=\frac{\text { Weight of HAp }(\mathrm{g})}{\text { Weight of fish bone }(\mathrm{g})} \times 100 \%
$$

\section{Colour}

Colour analysis was carried out using Chromameter (Konica Minolta CR-400, Japan). The chromameter device was then firmly pressed onto the Petri dish containing the samples as shown in Figure 1. The colour parameter of the samples was calculated according to the following equation (Pathare et al., 2013):

$$
\Delta E_{L^{*} a^{*} b^{*}}=\sqrt{\left(L^{*}-L_{0}\right)^{2}+\left(a^{*}-a_{0}\right)^{2}+\left(b^{*}-b_{0}\right)^{2}}
$$

*Parameter of white colour (reference): $L^{*}=$ $100, a^{*}=0, b^{*}=0$

Parameter $L^{*}$ refers to the lightness of the sample. It ranges from black $(L=0)$ to white $(L=100)$. The negative value of parameter $a^{*}$ indicates a green colour and a positive value indicates a red-purple colour. The positive value of parameter $b^{*}$ indicates a yellow colour and a negative value indicates a blue colour. $L_{0}, a_{0}$ and $b_{0}$ indicate colour parameters of the reference colour.

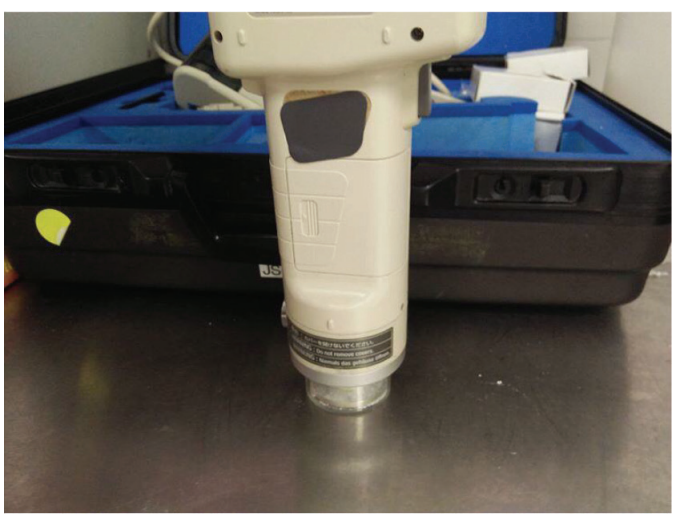

Figure 1: Measurement procedure of colour analysis

\section{Scanning Electron Microscopy}

Scanning electron microscopy (SEM) was conducted according to the method of Boutinguiza et al. (2012) to identify the morphological structure of RB, HAp-1 and standard hydroxyapatite (HAp-2). The samples were attached on a copper holder and coated with gold for 30 seconds at $20 \mathrm{kV}$ and observed under a microscope (JEOL JSM6610LV, USA). 


\section{Energy Disperse Spectroscopy}

Energy Disperse Spectroscopy (EDS) analysis was carried out according to the method of Boutinguiza et al. (2012). The calcium-tophosphorus $\mathrm{Ca} / \mathrm{P}$ atomic ratio of $\mathrm{RB}, \mathrm{HAp}-1$ and HAp-2 was calculated and determined by a Scanning Electron Microscope (JEOL JSM6360LA, Japan) equipped with an EDAX detector for energy dispersive microanalysis (EDX) to analyse local chemical composition.

\section{Statistical analysis}

Analysis of Variance (ANOVA) and multiple comparisons (Post hoc test) were applied in this study and the level of significance was $\alpha=0.05$ (two-sided). Statistical analyses were performed using SPSS for Windows (version 23.0).

\section{Results and Discussion}

\section{Extraction of hydroxyapatite}

The extraction of hydroxyapatite (HAp) through heat treatment of spotted sardinella (Amblygaster sirm) bone in this study was carried out at temperatures of $600,700,800,900$ and $1000^{\circ} \mathrm{C}$ to optimize the method for obtaining pure HAp. These ranges of temperatures were followed from previously described temperatures and had been optimized in terms of yield and colour. The temperatures from 600 to $1000^{\circ} \mathrm{C}$ are the common range of calcination temperature for the formation of HAp with chemical formula of $\mathrm{Ca}_{10}\left(\mathrm{PO}_{4}\right)_{6}\left(\mathrm{OH}_{2}\right)$ through the decomposition of water, organic and other inorganic materials in the bone. The optimum temperature of the HAp extraction is varied depending on the source for obtaining the pure particles. The transition phase for the formation of HAp in this study was found at $700^{\circ} \mathrm{C}$ and it had been confirmed by Energy Disperse Spectroscopy (EDS). The transition phase of calcium phosphate materials of spotted sardinella (Amblygaster sirm) bone is illustrated in Figure 2.

The formation of HAp in this study was calcium deficient HAp or non-stoichiometric HAp with calcium-to-phosphorus $(\mathrm{Ca} / \mathrm{P})$ atomic ratio 1.64 which is closer to the stoichiometric ratio of HAp (1.67). The non-stoichiometric HAp is usually derived from biological source material such as the bone of animal and scale of fish. According to Dorozhkin (2012) that the non-stoichiometric $\mathrm{Ca} / \mathrm{P}$ atomic ratio of HAp ranges from 1.5 to 1.67 . In contrast, the stoichiometric HAp is commonly obtained from chemical processes with the $\mathrm{Ca} / \mathrm{P}$ atomic ratio is 1.67 .

A study from Sunil \& Jagannatham (2016) stated that the transition phase of the HAp formation using roho labio fish bone was consistent from temperature 700 to $1000^{\circ} \mathrm{C}$ with $\mathrm{Ca} / \mathrm{P}$ atomic ratio was 1.63 . The uses of new species of spotted sardinella (Amblygaster sirm) fish bone in this study can fulfil the gap of method development through the uses of novel biological source for HAp extraction. The optimum temperature that was found in this study $\left(700^{\circ} \mathrm{C}\right)$ was further characterised in terms of proximate composition, morphological characteristic and $\mathrm{Ca} / \mathrm{P}$ atomic ratio.

\section{Proximate analysis}

Proximate content of raw bone (RB) and extracted nano-hydroxyapatite (HAp-1) were analysed to determine the protein, ash, moisture and lipid content. Table 1 shows the percentage of proximate composition (\%) of RB and HAp1.

The table above demonstrates the percentage of protein, ash, moisture and lipid contents in

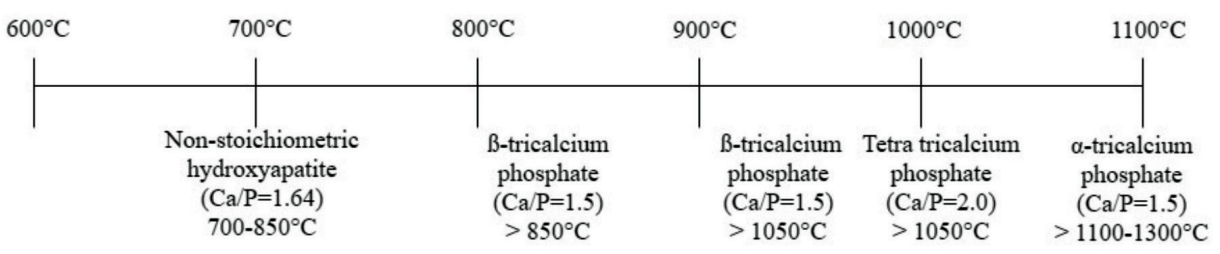

Figure 2: Transition phase of calcium phosphate materials of spotted sardinella (Amblygaster sirm) bone 
Table 1: Percentage of proximate composition (\%) of RB and HAp-1

\begin{tabular}{lcc}
\hline \multicolumn{1}{r}{ Composition } & RB (\%) & HAp-1 (\%) \\
\hline Protein & $1.08 \pm 0.47$ & $2.69 \pm 0.16$ \\
Ash & $50.98 \pm 0.69$ & $98.24 \pm 0.98$ \\
Moisture & $10.47 \pm 1.33$ & $0.53 \pm 0.33$ \\
Lipid & $3.78 \pm 1.04$ & $0.62 \pm 0.13$ \\
\hline
\end{tabular}

*Values are given as mean \pm SD from triplicate determinations.

*RB: Raw bone

*HAp-1: Extracted nano-hydroxyapatite

RB and HAp-1. Figure 3 shows a comparison of the percentage of proximate composition (\%) of RB and HAp-1.

The result showed that the percentage of protein content in HAp-1 (2.69\%) was higher compared to RB (1.08\%). This phenomenon may be due to the high content of organic and inorganic components in HAp-1. This finding was supported by Hemung (2013), who found that the amount of protein in tilapia bone powder is $14.81 \%$. This finding indicates that protein is an important component that gives strength and hardness to the bone structure. This finding was further supported by another study from Toppe et al., (2007) who found that the percentage of protein content in salmon bone is below $1.00 \%$.

Percentage of ash content in HAp-1 (98.24\%) was higher compared to RB (50.98\%) probably due to the high composition of materials such as protein and lipid. This finding was in alignment with the previous study by Benjakul et al. (2017), who found that the amount of ash content in the calcined bone of skipjack tuna is $99.75 \%$ due to the high amount

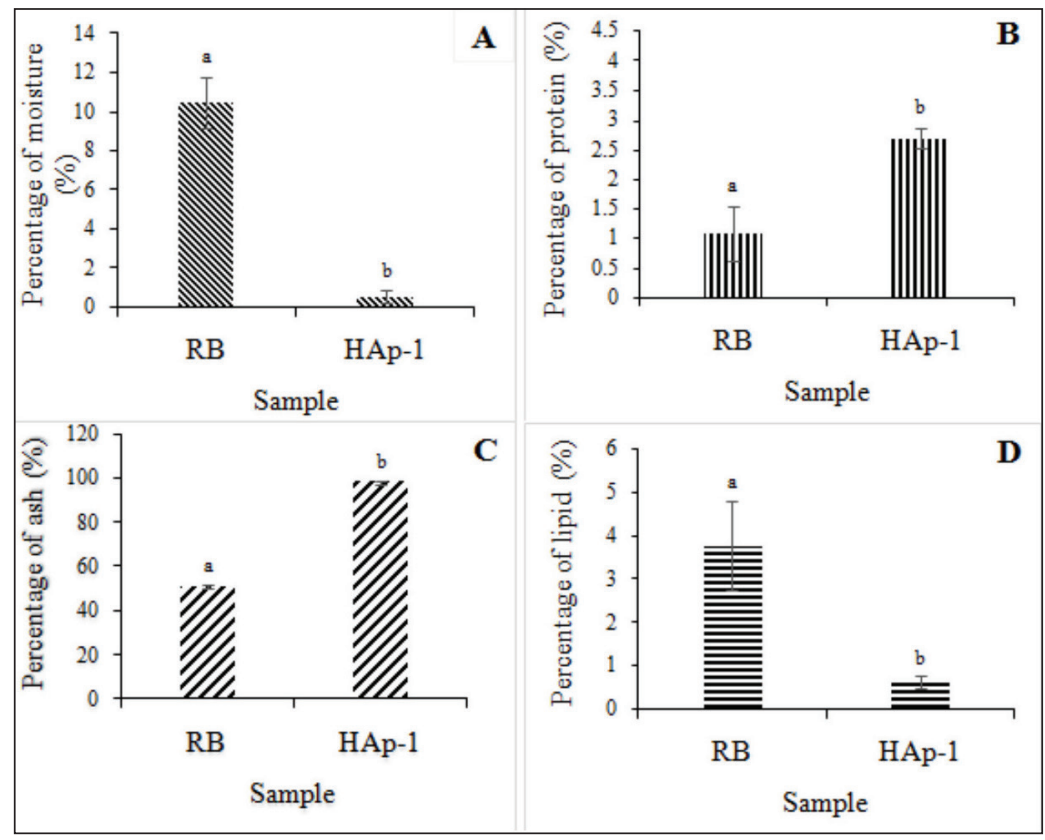

Figure 3: Comparison of moisture (A), protein (B), ash (C) and lipid (D) contents in RB and HAp-1.

$*$ Values are given as mean \pm SD from triplicate determinations.

*RB: Raw bone

*HAp-1: Extracted nano-hydroxyapatite 
of organic matter such as fat and protein. The ash content in fish bone is normally more than $40 \%$ depending on species (Toppe et al., 2007).

Percentage of moisture content in HAp$1(0.53 \%)$ was lower than RB (10.47\%). This phenomenon may be due to the complete combustion during calcination. This finding was supported by Hemung (2013), who found that the small amount of moisture present in the fish bone is due to incomplete drying.

Percentage of lipid content in HAp-1 $(0.62 \%)$ was lower compared to RB $(3.78 \%)$. This phenomenon may be due to the complete decomposition of materials during calcination. This finding is supported by Toppe et al. (2007), who found that the amount of lipid in mackerel bone is $47 \%$. This finding is further aligned by Johns (1999), who found that the percentage of lipid content in the fish bone ranged from 1 to $47 \%$.

\section{Percentage of Yield}

Yield percentage of HAp-1 was calculated to determine the amount of HAp obtained for each of the temperatures. Table 2 shows the yield percentage of HAp-1 extracted at different temperatures.

Based on the results, the yield percentage of HAp- 1 extracted at $600^{\circ} \mathrm{C}, 700^{\circ} \mathrm{C}, 800^{\circ} \mathrm{C}$, $900^{\circ} \mathrm{C}$ and $1000^{\circ} \mathrm{C}$ were $53.67 \%, 45.90 \%$, $52.45 \%, 49.25 \%$ and $52.18 \%$, respectively. The yield percentage decreased with the increase of temperatures. The highest yield percentage was obtained at a temperature of $600^{\circ} \mathrm{C}$ with $53.67 \%$. This phenomenon may be due to the sample still containing the remaining organic components and a low degree of purity. This finding is supported by Venkatesan and Kim (2010) who found that the yield percentage of extracted HAp is less than $60 \%$ and with the colour changing to white it indicates a high degree of purity. The HAp-1 in this study was found to be lower compared to bovine bone and tilapia scale (Barakat et al., 2009; Mustafa et al., 2015). However, it was found to be higher than cattle bone, tuna bone and carp fish scale (Al-Sokani et al., 2009; Sutapa et al., 2016; Muhammad et $a l ., 2016)$. The production of HAp using spotted sardinella (Amblygaster sirm) bone is still economical compared to other previous studies. The yield percentage of HAp-1 was consistent for all temperatures and there is no significant difference at $\alpha=0.05$. This phenomenon could be due to the complete combustion and thermal stability of the bone achieved at temperature $600^{\circ} \mathrm{C}$ and above. The optimum temperature for HAp extraction was further evaluated using colour analysis.

\section{Colour}

The colour of HAp-1 was further analysed using naked eyes and chromameter device based on the $L^{*} a^{*} b^{*}$ model. Figure 4 shows the comparison of the colour of the bone heated at different temperatures.

Table 2: Yield percentage of HAp-1 from spotted sardinella (Amblygaster sirm) bone extracted at different temperatures

\begin{tabular}{ccc}
\hline Temperature $\left({ }^{\circ} \mathbf{C}\right)$ & Duration $(\mathbf{h})$ & Yield (\%) \\
\hline 600 & 5 & $53.14 \pm 0.46^{\mathrm{a}}$ \\
700 & 5 & $51.36 \pm 0.37^{\mathrm{a}}$ \\
800 & 5 & $52.80 \pm 0.85^{\mathrm{a}}$ \\
900 & 5 & $51.35 \pm 0.10^{\mathrm{a}}$ \\
1000 & 5 & $50.46 \pm 0.81^{\mathrm{a}}$ \\
\hline
\end{tabular}

*Values are given as mean \pm SD from triplicate determinations.

*HAp-1: Extracted nano-hydroxyapatite 
Based on Figure 4, the colour of the bone is varied depending on calcination temperatures. Calcination of bone at $700^{\circ} \mathrm{C}$ produced the lightest white colour compared to other temperatures based on naked eyes. The colour of the bone may be influenced by the transitional phase of the bone composition for the formation of calcium phosphate material. The colour of the bone heated at different temperatures was further evaluated using chromameter to analyse the colour changes of the bone. Table 3 shows colour changes $(\Delta \mathrm{E}) \mathrm{RB}, \mathrm{HAp}-1$ and standard hydroxyapatite (HAp-2). The colour characteristic is important which indicates the quality of HAp. Data was stored in $L^{*} a^{*} b^{*}$ colour model and colour changes $(\Delta \mathrm{E})$ were calculated with white colour parameter as a reference colour.

The result demonstrated that colour changes of HAp-1 at a temperature of $700^{\circ} \mathrm{C}$ shows the lowest value $(\Delta \mathrm{E}=17.89)$ compared to $\mathrm{RB}$ and HAp- 1 extracted at $600^{\circ} \mathrm{C}, 800^{\circ} \mathrm{C}, 900^{\circ} \mathrm{C}$ and $1000^{\circ} \mathrm{C}$. This phenomenon may be due to the complete combustion and high degree of purity achieved. This finding is further supported by Venkatesan and Kim (2010), who found that the white colour of the powder indicates the formation of pure HAp. The transition phase of HAp for spotted sardinella (Amblygaster sirm) bone was in the range of 700 to $800^{\circ} \mathrm{C}$ based on the colour formation. This finding was further supported by Liao et al. (2014) who stated that the transition phase for the formation of HAp was found at the range of 700 to $850^{\circ} \mathrm{C}$. According to Sofronia et al. (2014) who stated that the optimum temperature for HAp extraction using bovine bone was found at $800^{\circ} \mathrm{C}$. There is a significant difference in colour changes in the value for each temperature for spotted sardinella (Amblygaster sirm) bone.

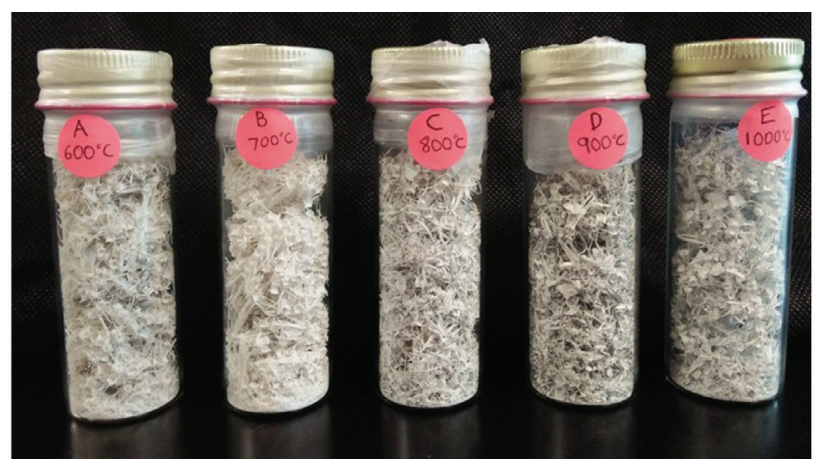

Figure 4: Comparison of the colour of spotted sardinella bone heated at different temperatures

Table 3: Colour changes $(\Delta \mathrm{E})$ of RB, HAp-1 and HAp-2

\begin{tabular}{cccc}
\hline Type of sample & Temperature $\left({ }^{\circ} \mathbf{C}\right)$ & Colour changes $(\Delta \mathbf{E})$ & Colour of sample \\
\hline RB & & $34.23 \pm 0.69^{\mathrm{a}}$ & Yellowish \\
HAp-1 & 600 & $29.04 \pm 2.86^{\mathrm{a}}$ & Yellowish white \\
HAp-1 & 700 & $17.89 \pm 0.36^{\mathrm{b}}$ & White \\
HAp-1 & 800 & $22.11 \pm 0.97^{\mathrm{b}}$ & White \\
HAp-1 & 900 & $24.75 \pm 0.06^{\mathrm{b}}$ & White \\
HAp-1 & 1000 & $19.26 \pm 0.66^{\mathrm{b}}$ & White \\
Standard HAp & & $5.85 \pm 0.39^{\mathrm{c}}$ & White \\
\hline
\end{tabular}

*Values are given as mean $\pm \mathrm{SD}$ from triplicate determinations.

*RB: Raw bone

*HAp-1: Extracted nano-hydroxyapatite

*HAp-2: Standard hydroxyapatite

Journal of Sustainability Science and Management Volume 15 Number 8, December 2020: 9-21 
Therefore, calcination temperature at $700^{\circ} \mathrm{C}$ is considered as the optimum temperature for HAp extraction in this study. The transition phase of HAp at the optimum temperature was further evaluated, the $\mathrm{Ca} / \mathrm{P}$ atomic ratio to confirm the formation of HAp.

\section{Scanning Electron Microscopy}

Scanning Electron Microscopy (SEM) was conducted to observe the morphological structure of RB, HAp-1 and HAp-2. Figure 5 shows the SEM images of RB, HAp- 1 and HAp-2 under magnification of 100X, 4,300X and 200X; respectively.
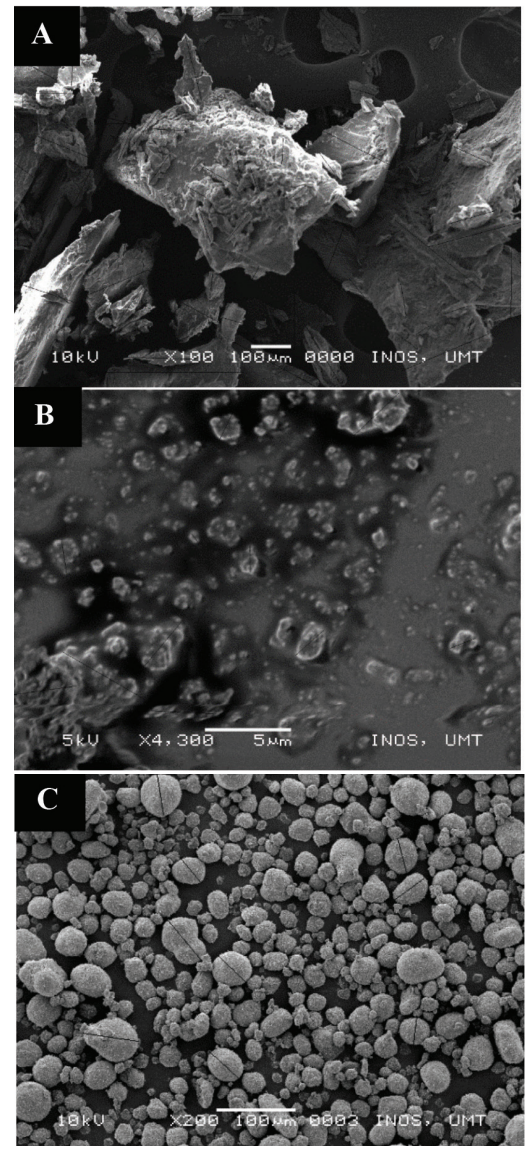

Figure 5: SEM images of RB (A), HAp-1 (B) and HAp-2 (C). Magnification: 100X, 4,300X and 200X.

*RB represents: Raw bone Volt: $5 \mathrm{kV}, 10 \mathrm{kV}$

*HAp-1: Extracted nano-hydroxyapatite

*HAp-2: Standard hydroxyapatite
The result demonstrated that the morphological structure of RB showed amorphous shape and size consisting of decomposed inorganic materials and smallsized HAp particle. This phenomenon could be due to the composition of inorganic materials contained in the RB, including HAp particle. The particle size of RB seems to have larger particle structure compared to the HAp-1 and HAp-2 due to the packed structure of particles with a combination of inorganic materials such as collagen protein and HAp crystal. This finding is further supported by Sutapa et al. (2016), who stated that the raw bone consists of inorganic materials including collagen, fat, protein and minerals compound which decomposes after the calcination process except for HAp.

HAp-1 exhibited smaller particle and irregular sphere-like shape compared to the ones observed for RB and HAp-2. The morphological structure of HAp-1 was found to be agglomerated consisting of tiny crystal particle (Adak \& Purohit, 2011). This phenomenon may be due to the effect of the milling process and influenced by the calcination temperature that leads to the formation of the agglomerated nano-sized particle after the milling process (Sofronia et al., 2014). This study is supported by Sun et al. (2017), who found a similar finding on the structure of calcined-HAp which has an irregular shape. The size of HAp-1 was in the range of nanoparticles size with inconsistent shape. The production of HAp from biological sources is commonly exhibited the shape of the particles with slightly inconsistent in shape and size. This phenomenon is related to the composition, properties of the bone and effect of milling process that contributed to the shape and size of the HAp particles. According to Venkatesan et al. (2015) the morphological characteristic of HAp extracted from salmon fish bone was agglomerated and are irregular particles. The finding in this study was further supported by Sunil \& Jagannatham (2016) who mentioned that the SEM images of HAp extracted from roho labio fish bone exhibited large agglomerated particles. Other researchers (Coelho et al., 2007; Mondal et al., 2012; Corrêa \& Holanda, 
2019) also reported that the SEM images of nanostructure of HAp extracted from fish bone demonstrated agglomerated and are irregular particles. The comparison of SEM images of this study with previous studies is in alignment with the structure of fish bone HAp that demonstrated an agglomerated and inconsistent HAp particle with variation in particle size distribution.

The HAp-2 exhibited larger particle size with spherical shape compared to the ones observed for RB and HAp-1. The increase of calcination temperature influenced the grain growth and crystallization of HAp particle due to the absorption of heat energy during chemical synthesis process (Guo et al., 2013; Khoo et al., 2015). This finding is further supported by Sun et al. (2017), who found similar conclusions on the morphological structure formed by standard HAp particle which has a spherical shape.

\section{Calcium-to-phosphorus ratio}

$\mathrm{Ca} / \mathrm{P}$ ratio of hydroxyapatite (HAp) was determined by Energy Disperse Spectroscopy (EDS). Figure 6 shows the $\mathrm{Ca} / \mathrm{P}$ ratio of $\mathrm{RB}$, HAp-1 and HAp-2. Ca/P ratio of HAp is a vital characteristic which confirms the purity of the extracted HAp.
The result demonstrated that the $\mathrm{Ca} / \mathrm{P}$ ratios of RB, HAp-1 and HAp-2 were 3.18, 1.64 and 1.64 respectively. The $\mathrm{Ca} / \mathrm{P}$ ratio of $\mathrm{RB}$ demonstrated slightly higher value compared to HAp-1 and HAp-2. This phenomenon could be due to the variation of the element in the raw bone which influences the ratio. The $\mathrm{Ca} / \mathrm{P}$ ratio of HAp-1 and HAp-2 exhibited a lower value than the theoretical stoichiometric ratio of HAp. However, it is an acceptable range for HAp non-stoichiometric molar ratio which ranges from 1.56 to 1.86 (Barakat et al., 2009). This finding is further supported by Michael et al. (2016) who stated that the extracted $\mathrm{HAp}$ at different conditions show a high $\mathrm{Ca} / \mathrm{P}$ ratio which is $1.74,1.81$ and 1.87 . The nonstoichiometric $\mathrm{Ca} / \mathrm{P}$ ratio of HAp in this study may be contributed by the source of extraction. The non-stoichiometric ratio also indicates the extracted HAp is calcium-deficient type. The HAp obtained from natural sources is usually possesses a non-stoichiometric $\mathrm{Ca} / \mathrm{p}$ molar ratio that can be varied within the range of 1.56 to 1.86. It is different from stoichiometric HAp which has a constant $\mathrm{Ca} / \mathrm{P}$ molar ratio (1.67).

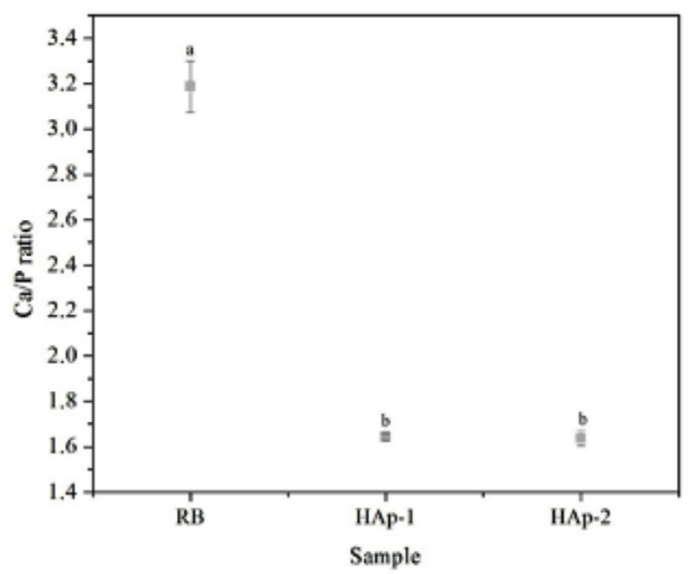

Figure 6: $\mathrm{Ca} / \mathrm{P}$ ratio of $\mathrm{RB}, \mathrm{HAp}-1$ and HAp-2

*Values are given as mean \pm SD from triplicate determinations.

*RB: Raw bone

*HAp-1: Extracted nano-hydroxyapatite

*HAp-2: Standard hydroxyapatite 


\section{Conclusion}

The extracted nano-hydroxyapatite (Nano-HAp) extracted from spotted sardinella (Amblygaster sirm) bone can be an alternative to the synthetic hydroxyapatite (HAp). This is because the NanoHAp extracted from this fish demonstrated high yield (50 to 53\%). Morphological structure of HAp was observed to exhibit a sphericallike shape with agglomerated structure. The shape of Nano-HAp is an important factor that can influence its properties, performance and compatibility to be used in a certain application. The overall finding suggested that the extracted Nano-HAp from this fish can be potentially commercialised for any market and could be used as a potential biomaterial for many applications.

\section{Acknowledgements}

The author would like to acknowledge the support of the Faculty of Fisheries and Food Sciences (FPSM), the Faculty of Ocean Engineering Technology and Informatics (FTKKI) and the Institute of Oceanography and Environment (INOS) for accessibility to facilities and materials upon completing the experiments. This research did not receive any specific grant from funding agencies in the public, commercial, or not-for-profit sectors.

\section{References}

Adak, M. D., \& Purohit, K. M. (2011). Synthesis of nano-crystalline hydroxyapatite from dead snail shells for biological implantation. Trends in Biomaterials and Artificial Organs, 25(3),101-106.

Al- Sokanee, Z., Toabi, A. A. H., Al- Assadi, M. J., \& Alassadi, E. A. S. (2009). The drug release study of ceftriaxone from porous hydroxyapatite scaffolds. An Official Journal of the American Association of Pharmaceutical Scientists,15(5), 116311171.

AOAC. (2000). Official methods of analysis (17th ed.). Washington, DC: Association of Official Analytical Chemists.
Bahrololoom, M. E., Javidi, M., Javadpour, S., \& Ma, J. (2009). Characterisation of natural hydroxyapatite extracted from bovine cortical bone ash. Journal of Ceramic Processing Research, 10(2), 129-138.

Barakat, N. A. M., Khil, M. S., Omran, A. M., Sheikh, F. A., \& Kim, H. Y. (2009). Extraction of pure natural hydroxyapatite from the bovine bones bio waste by three different methods. Journal of Material Processing Technology, 209(7), 3408-4315.

Benjakul, S., Mad-Ali, S., Senphan, T., \& Sookchoo, P. (2017). Biocalcium powder from precooked skipjack tuna bone: Production and its characteristics. Journal of Food Biochemistry, 41(6), 1-8.

Ben-Nissan, B., Milev, A., \& Vago, R. (2004). Morphology of sol-gel derived nano-coated coralline hydroxyapatite. Biomaterials, 25(20), 4971-4975.

Boutinguiza, M., Pou, J., Comesaña, R., Lusquiños, F., de Carlos, A., \& León, B. (2012). Biological hydroxyapatite obtained from fish bones. Materials Science and Engineering, 32(3), 478-486.

Coelho, T. M., Nogueira, E. S., Weinand, W. R., Lima, W. M, Steimacher, A., Medina, A. N., Baesso, M. L., \& Bento, A. C. (2007). Thermal properties of natural nanostructured hydroxyapatite extracted from fish bone waste. Journal of Applied Physics, 101(8), 1-6.

Corrêaa, T. H. A., \& Holanda, J. N. F. (2019). Fish bone as a source of raw material for synthesis of calcium phosphate. Materials Research, 22(1), 1-5.

Dorozhkin, S. V. (2012). Amorphous calcium orthophosphates: Nature, chemistry and biomedical applications. International Journal of Materials and Chemistry, 2(1), 19-46.

Elvevoll, E. O., \& James, D. (2001). The emerging importance of dietary lipids, quantity and quality, in the global disease burden: the potential of aquatic resources. Nutrition and Health, 15(3-4), 155-167. 
Elvevoll, E. O., \& Osterud, B. (2003). Impact of processing on nutritional quality of marine food items. Forum of Nutrition, 56(2003), 337-340.

Guo, X., Yan, H., Zhao, S., Li, Z., Li, Y., \& Liang, $X$. (2013). Effect of calcining temperature on particle size of hydroxyapatite synthesized by solid-state reaction at room temperature. Advanced Powder Technology, 24(6), 1034-1038.

Hemung, B. (2003). Properties of tilapia bone powder and its calcium bioavailability based on transglutaminase assay. International Journal of Bioscience, Biochemistry and Bioinformatics, 3(4), 306-309.

Johns P. (1977). The structure and components of collagen containing tissues in Ward. The Science and Technology of Gelation. London: Academic Press. 31-72.

Karim, S. A., Asri, A. S. M., Mamat, S., Mohamed, M., Shohaimi, N. A. M., Halim, A. Z. A., Shukri, N. M., \& Abdullah, N. H. (2019). Synthesis and characterization of hydroxyapatite powder from fish bones and scales using calcination method. International Journal of Advanced Science and Technology, 28(18), 82-87.

Khoo, W., Nor, F.M., Ardhyananta, H., \& Kurniawan, D. (2015). Preparation of natural hydroxyapatite from bovine femur bones using calcination at various temperatures. Second International Materials, Industrial, and Manufacturing Engineering Conference, 2(2015), 196 201.

Kong, L. B., Ma, J., \& Boey, F. (2002). Nanosized hydroxyapatite powders derived from co precipitation process. Journal of Materials Science, 37(6), 1131-1134.

Liao, J., Duan, X., Li, Y., Zheng, C., Yang, Z., Zhou, A., \& Zou, D. (2014). Synthesis and mechanism of tetracalcium phosphate from nanocrystalline precursor. Journal of Nanomaterials, 2014(4), 1-11.
Liu, D-M., Yang, Q., Troczynski, T., \& Tseng, W. J. (2002). Structural evolution of solgel derived hydroxyapatite. Biomaterials, 23(7), 1679-1687.

Liu, J., Li, K., Wang, H., Zhu, M., \& Yan, H. (2004). Rapid formation of hydroxyapatite nanostructures by microwave irradiation. Chemical Physics Letters, 396(4-6), 429432.

Liu, W. T., Zhang, Y., Li, G. Y., Miao, Y. Q., \& Wu, X. H. (2008). Structure and composition of teleost scales from snakehead Channaargu (Cantor) (Perciformes: Channidae). Journal of Fish Biology, 72(4), 1055-1067.

Michael, F. M., Khalid, M., Ratnam, C. T., Chee, C. Y., Rashmi, W., \& Hoque, M. E. (2016). Sono-synthesis of nanohydroxyapatite: Effects of process parameters. Ceramics International, 42(5), 6263-6272.

Mobasherpour, I., Soulati,Heshajin, M., Kazemzadeh, A., \& Zakeri, M. (2007). Synthesis of nanocrystalline hydroxyapatite by using precipitation method. Journal of Alloys and Compounds, 430(1-2), 330-333.

Mondal, S., Mondal, B., Dey, A., \& Mukhopadhyay, S. S. (2012). Studies on processing and characterization of hydroxyapatite biomaterials from different bio wastes. Journal of Minerals \& Materials Characterization \& Engineering, 11(1), 5567.

Muhammad, N., Gao, Y., Iqbal, F., Ahmad, P., \& Ge, R. (2016). Extraction of biocompatible hydroxyapatite from fish scales using nvel approach of ionic liquid pretreatment. Separation and Purification Technology, 161(2016), 129-135.

Mustafa, N., Ibrahim, M. H. I., Asmawi, R., \& Amin, A. M. (2015). Hydroxyapatite extracted from waste fish bones and scales via calcination method. Applied Mechanics and Materials, 773-774(2015), 287-290.

Ozawa, M., \& Suzuki, S. (2002). Microstructural development of natural hydroxyapatite originated from fish bone waste through 
heat treatment. Journal of the American Ceramic Society, 85(5), 1315-1317.

Ozgur, N. E., \& Cuneyt, T. A. (1999). Manufacture of macroporous calcium hydroxyapatite and tri-calcium phosphate bioceramics. Journal of the European Ceramic Society, 19(1999), 2569-2572.

Pathare, P. B., Opara, U. L., \& Al-Said, F. A. J. (2013). Colour measurement and analysis in fresh and processed foods: A Review. Food and Bioprocess Technology, 6(1), 36-60.

Ratnasari, I., \& Firlianty. (2016). Physicochemicalcharacterizationandskin gelatin rheologyoffourfreshwaterfish as alternative gelatin source. International Journal of Bioflux, 9(6), 1196-1207.

Rozaini, M. Z. H., Hamzah, H., Mohtar, N. F., Sainoruddin, M. H., Sofian, Mohd Ghazali, M. S., Abd Wahid, M. E., Razali, M. H., Ghazali, S. R., Ibrahim, N. H., \& Fei, L. C. (2017). Biomaterials derived from Sardinella Fimbriata (Tamban) bones as promising anodyne sunscreen. Journal of Sustainability Science and Management Special, (3), 99-110.

Sanosh, K. P., Chu, M. C., Balakrishnan, A., Kim, T. N., \& Cho, S. J. (2009). Utilization of biowaste eggshells to synthesize nanocrystalline hydroxyapatite powders. Materials Letters, 63(24-25), 2100-2102.

Sofronia, A. M., Baies, R., Anghel, E. M., Marinescu, C. A., \& Tanasescu, S. (2014). Thermal and structural characterization of synthetic and natural nanocrystalline hydroxyapatite. Materials Science \& Engineering C, 43(2014), 153-163.
Sun, R. X., Lv, Y., Niu, Y. R., Zhao, X. H., Cao, D. S., Tang, J., \& Chen, K. Z. (2001). Physicochemical and biological properties of bovine-derived porous hydroxyapatite/ collagen composite and its hydroxyapatite powders. Ceramics International, 43(18), 16792-16798.

Sunil, B. R., \& Jagannatham, M. (2016). Producing hydroxyapatite from fish bones by heat treatment. Materials Letters, 185(2016), 411-414.

Sutapa, I. W., Romawaty, \& Bandjar, A. (2016). Synthesis $\mathrm{Ca}^{3}\left(\mathrm{PO}_{4}\right)^{2}$ from tuna fish bone and potential as a catalyst in the transesterification reaction for biodiesel production. Journal of Chemical and Pharmaceutical Research, 8(8), 596-604.

Toppe J, Albrektsen, S., Hope, B., \& Aksnes, A. (2007). Chemical composition, mineral content and amino acid and lipid profiles in bones from various fish species. Comparative Biochemistry and Physiology $B, 146(3), 395-401$.

Venkatesan, J., \& Kim, S. K. (2010). Effect of temperature on isolation and characterization of hydroxyapatite from tuna (Thunnusobesus) bone. Materials, 3(10), 4761-4772.

Venkatesan, J., Lowe, B., Manivasagan, P., Kang, K-H., Chalisserry, E. P., Anil, S., Kim, D. G., \& Kim, S. K. (2015). Isolation and characterization of nano-hydroxyapatite from salmon fish bone. Materials, 2015(8), 5426-5439. 